\title{
Letter from . . . Sydney
}

\section{Australian doctors on strike}

\author{
PETER C ARNOLD
}

"As far as the members of the medical profession themselves are concerned, there can be no doubt that the nature of their calling as doctors, surgeons and nurses imposes on them a moral duty never to strike or to engage in any action designed to reduce the level of service provided, no matter how deep or bitter their sense of grievance."1

Many within and without the profession would agree with Professor Macfarlane's claim. Yet nurses' strikes are almost beyond counting. Preliminary research shows that doctors have taken strike action in at least 17 Western countries, in many of which there have been more than one strike. Now Australia has had its first doctors' strike. An understanding of this event requires some knowledge of recent changes in health insurance arrangements. The system before February 1984 has been described recently. ${ }^{2}{ }^{3}$

Australia has a comprehensive system of public (state owned) and private (charity or commercial) hospitals. The current dispute concerns the conditions under which consultants may treat private, fee paying patients in public hospitals. For decades consultants have offered their services free of charge in the public hospitals, treating the indigent and teaching medical and nursing students. In exchange these "honoraries" could admit private patients. The public hospitals also employed staff specialists, fully salaried but with the right to treat some private patients.

Over the past 15 years Australia has experienced a variety of health insurance schemes. The costs of medical and hospital care have been shared-in varying proportions, at different times, in many schemes-between the federal government, the state governments, and the voluntary health insurance "funds" (British United Provident Association type organisations*). Each change of government policy has resembled a game of musical chairs, with the major responsibility for costs being tossed around between the governments and the funds like the proverbial hot potato. In New South Wales, where specialists led the recent strike, the state government decided some years ago on a novel method of economising on staff specialists' salaries. It offered them the opportunity of treating more private patients in exchange for a substantial reduction in salary. As the patients' fees were met through the funds, which were in turn subsidised by the federal government, a clever New South Wales government was able to pass the buck.

The specialists most affected were those in pathology, radiology, and nuclear medicine. Their work, as is usual in these specialties, consists of the interpretation of data obtained

${ }^{*}$ More like the Blue Cross and Blue Shield in the United States.

Vaucluse 2030, New South Wales, Australia

PETER C ARNOLD, BSC, $M B$

Correspondence to: "Nooitgedacht," 21A Olola Avenue, Vaucluse 2030, New South Wales, Australia. with the help of technicians using modern laboratory and radiological equipment. In their case, however, the technicians were employed by the hospitals which owned the equipment. The specialists paid an agreed percentage of each private fee for the use of these facilities. The vagaries of health insurance legislation were such that patients with private insurance could claim their reimbursements only if the accounts they received were from a doctor. Accounts submitted by hospitals for services regarded as "medical" were not eligible for reimbursement. Accordingly, the hospitals sent out accounts for $x$ ray examinations and for pathological tests in the name of the specialists who had verified the relevant reports. During this time many "honoraries" were persuaded to accept payment, on a sessional basis, for attention to non-insured patients.

\section{4 legislation}

On 1 February 1984, the Labour federal government's new Medicare plan (loosely based on the Canadian system) replaced the funds in respect of all insurance for medical expenses. It became illegal to offer or to purchase insurance against any costs for medical services covered by Medicare. The new legislation required pathologists and radiologists to sign a new contract with public hospitals; prohibited the reimbursement of fees to patients treated privately in public hospitals unless the specialist had signed the contract; specified that fees must be at the levels determined by the federal government's fee setting tribunal; and allowed the Minister of Health to vary any aspect of the contract without consultation with the profession and without any avenue of appeal against such variations.

Although the radiologists, pathologists, and nuclear medicine specialists were the only sections of the profession directly specified by the new regulations, other specialists-especially the surgeons-became concerned that they, too, might be affected by such contracts. As the pathologists had already been brought under substantial control by the federal government in 1979-in an (unsuccessful) attempt to diminish "overservicing" by unscrupulous pathologists paying "kick backs" to referring doctors-the radiologists and surgeons decided to make a stand on the question of the new contracts.

From 1 February all Australians started paying a $1 \%$ tax levy in exchange for cover for $85 \%$ of the fees determined by the government's tribunal as being appropriate for the many thousands of items of medical service rendered by doctors, and for the costs of hospital care in shared wards. Pathologists and radiologists were called on by the government to sign their contracts by $1 \mathrm{March}$, after which date, unless they had signed up, no reimbursements would be paid to their patients. In mid-February the Australian Medical Association announced that-apart from some minor matters to be decided by an independent committee of inquiry headed by the dean of the faculty of medicine at Melbourne University, Professor David Penington-it was in general agreement with the requirement that the contracts should be signed by 1 March. The Australian 
Medical Association had not appreciated the implications of the new Act.

\section{Radiologists' and surgeons' rebellion}

But the radiologists and the surgeons responded briskly. On 22 February the radiologists announced that they would not sign the contracts. A few days later the surgeons in New South Wales called for a stop to all but emergency surgery on 1 March. The radiologists and the New South Wales branch of the Australian Medical Association took up their call, and on that day no elective procedures were done in New South Wales public hospitals. The minister threatened that patients would not be reimbursed unless the doctors signed the contracts by 1 March and he requested his counterparts in the state governments to legislate for the control of the fees that doctors could charge for private work done in public hospitals. (For constitutional reasons the federal government is unable to legislate on doctors' fees. The state governments are, however, unrestricted in this regard.) The battle was on.

Over the next four weeks the public was entertained to full page newspaper advertisements placed by the orthopaedic and general surgeons, the radiologists, the Australian Medical Association, and the Minister for Health; to front page headlines about doctors striking and hospitals closing; to spirited radio and television clashes between the minister and the spokesmen for the various medical groups concerned; and to cartoons lampooning the doctors, who saw themselves as workers fighting for their rights. The Prime Minister joined in the discussions, at first secretly and then publicly, accusing the Australian Medical Association of being comparable to that most rumbustious and disruptive of all Australian trade unions, the Builders' Labourers' Federation. The public joined in through phone-ins to radio stations and through letters to the newspapers.

Some saw doctors as being greedy; others agreed that they, too, would refuse a contract that gave their employer unfettered powers over their conditions of work. The Labour governments of New South Wales, Victoria, South Australia, and Western Australia legislated to control doctors' fees in public hospitals. South Australia's unions called for a boycott of doctors opposed to the new legislation.

Meanwhile the strike had begun. Doctors in the Australian Capital Territory, the small district that contains the capital city of Canberra, banned all non-emergency public hospital work from 14 March. At the same time, New South Wales radiologists restricted their public hospital work to emergencies. New South Wales public hospital surgeons and other specialists held an emergencies only strike one day each week, rotating the day of the week so that no operation would be delayed more than a week. Doctors in other states threatened strike action. Finally, the Australian Medical Association announced a full week's emergencies only strike.

The Australian Medical Association called for a public rally by doctors, but cancelled it when Sydney's trade unions threatened the personal safety of doctors participating in the rally. The New South Wales government gazetted regulations prohibiting doctors from discussing with their private patients whether they would be admitted to public hospitals as private or as public patients.

Meanwhile the small Australian Democrat Party, which holds the balance of power in the federal senate, used its numbers to amend the legislation: now any changes to the contracts which the minister might make can be vetoed by either house of parliament. Finally, the minister conceded that he would refer all the contentious issues to the Penington inquiry. Both he and the Australian Medical Association, however, have made it clear that neither side considers itself obliged to abide by Penington's recommendations.

What observations can be made, in this Penington lull, about the participants in this confrontation? The Labour government announced, in broad principle, its intentions vis à vis private medicine over 20 years ago when formulating its policies on health care. At no time have these [Fabian] policies been varied. At each opportunity that it has had-under Whitlam in 1972-5 and, since 1983, under Hawke-Labour has tried to introduce appropriate legislation. Its universal, comprehensive Medibank was established in 1975, ran for just one year and was then progressively dismantled by the conservative Fraser government from 1976 onwards. Labour prefers salaried to private medicine, views private doctors as motivated primarily by greed, sees no reason why money should buy better medical care for some, and is determined to cut down the "tall poppies" in the profession.

Over recent decades the Australian Medical Association has in my view progressively lost its once unchallenged role as spokesman for the profession. Its members have become angered by its attempts to represent the interests of both salaried doctors and self employed doctors, general practitioners and specialists, doctors willing to be subsidised by the state and independent practitioners wishing to practise privately, and so on. First challenged in 1968 by the formation of the General Practitioners' Society (of which I was the founding secretary), the Australian Medical Association has found that its inability to represent the diverse interests of the profession has led to the establishment of, among others, the Australian Association of Surgeons, the Australian Society of Anaesthetists, the Australian Society of Orthopaedic Surgeons, and the National Association of Medical Specialists, all medicopolitical organisations separate from the royal colleges to which their members also belong. The recent confrontation with the government suggests to me that the Australian Medical Association is no longer able to tell the government what its members will accept. The Australian Medical Association must now consult with the compact, independent organisations representing the radiologists (their Royal Australasian College, unlike the other colleges, does not eschew political action) the surgeons, the anaesthetists, and the orthopaedic surgeons before being able to parley with the government.

\section{Profession divided}

Some, seeing this division of the profession, caution that unity is strength and that if we do not hang together, we will assuredly hang separately. Others point to the numerous examples of the leaders of traditional national medical organisations negotiating away their members' independence. ${ }^{4}$ This school of thought encourages the formation of small groups with common vocational and regional interests, which can stand up to the government regardless of agreements which might be concluded between government and the Australian Medical Association.

After some initial confusion, the media took the line that, just as workers in Australia have their (minimum) wages set by the arbitration commission, so doctors should agree to have their (maximum) fees set by an independent tribunal. The cartoonists had a field day lampooning the traditionally golfing doctor, more concerned with money than with his patients' well being. The public, according to one survey, was evenly divided on the issue, most finding it difficult to understand. Another found the public two to one against the doctors.

As to doctors going on strike, it does seem, contrary to the views of Professor Macfarlane, that doctors can and do sense deep and bitter grievances, which warrant their reducing the level of service they provide. The majority of strikes by doctors this century have concerned either levels of remuneration or moves by governments, which were seen as threatening remuneration at some future date. Examples of such reductions of levels of service are those that took place in Austria between 1955 and 1962, Belgium in 1963, Canada in 1962 (Saskatchewan) and 1970 (Quebec), France in 1960 and 1982-3, Germany in 1923 and 1977, Great Britain in 1975-6, Israel in 1950 and 1983, 
Italy in the 1960s and in 1974, Peru in 1984, Sweden in 1957, and in the USA in 1975-6. One of the few strikes called on a matter of non-monetary principle was that led by Ludwig Hartmann in Germany in 1909-a strike for the patients' freedom of choice of doctor. It could be argued, however, that even that strike was financial, as the Hartmannbund was concerned that some doctors might be excluded from the panels whose members were assured of payment.

The Australian strike of 1984 fits into the broad pattern of the strikes referred to above. While the specialists protested that they almost invariably charge the fees suggested by the government, their fear was that the new legislation would give the minister the power to control their fees. Until now they have been content with the right to charge higher fees, a right that they have seldom exercised but are most reluctant to relinquish. Furthermore, the proposed legislation would have given the minister total power over the private earnings of all public hospital doctors, whether salaried staff specialists or visiting medical officers (the former "honoraries").

\section{Are medical strikes in evitable?}

Whether or not doctors resort to strike action probably depends largely on community attitudes to strikes over salaries and conditions of service. Australia has a long tradition of arbitration and conciliation in industrial disputes, with strikes frequently used by unions to press their claims. While earlier generations of junior doctors were willing to work long hours in exchange for the experience, today's residents and interns have become unionised, lodging logs of claims before arbitration courts and arguing over allowances for accommodation, meals, laundry, and car parking. Yet it was not from the ranks of the formerly unionised trainee specialists that Australia's strike emanated. This strike was led by the radiological and surgical establishment, the old guard to whom the very thought of striking would hitherto have been unthinkable.

There can be no doubt that their fear was of the financial consequences of the new legislation. It was in the state where the specialists felt most threatened, namely New South Wales, which has few private hospitals into which they could retreat from government controls, that striking was seen as appropriate. Labour governments understand strike action as being the worker's ultimate weapon. By striking, the specialists hoped to make the federal and state Labour governments realise the depth of their opposition to the legislation. In the states in which private facilities are plentiful, such as Victoria, Queensland, and South Australia, strike action was threatened-as an expression of support for the specialists in New South Wales.

It might be tempting to suggest that medical strikes are inevitable in the long run if the government controls all the purse strings in the delivery of health care. But the Netherlands' experience suggests that society's attitude towards the settling of disputes is paramount. Dutch doctors willingly accept fee increases in accordance with changes in the salaries of senior public servants. ${ }^{5}$ They let the public service association and the government negotiate and they accept the outcome. Strike action by Dutch doctors in these circumstances seems unlikely.

As regrettable as it may seem to Professor Macfarlane and to others who share his idealistic view of the healing professions, medical strikes have become a part of the armamentarium of government employed doctors in many countries. Australian specialists are no different from their colleagues who have gone on strike elsewhere in the world. Perhaps the sad lesson for us all is that doctors, as a group, are really no different from the rest of the society in which they live.

\section{References}

Macfarlane LJ. The right to strike. Harmondsworth: Penguin, 1981:138-9. Goldstein SGM. In search of an optimal health care system. Br Med $\mathcal{F} 1982$; $285: 824-8$.

$285: 824-8$. 1983;286:159-60.

Arnold PC. Crises down under. Br Med F 1979;i:107-8.

Glaser WA. Health insurance bargaining: foreign lessons for Americans. New York: Gardner Press, 1978:86-8.

(Accepted 18 fune 1984)
Sunburn, particularly in the fair skinned, is now thought to be largely responsible for the development of some types of malignant melanoma. Is ultraviolet light still recommended for treating psoriasis? Is the incidence of cutaneous malignant neoplasia high in psoriasis?

The inquirer is correct in suggesting that several recent studies have suggested that fair skinned patients who burn easily are more commonly found in groups of patients suffering from melanoma than in age matched control groups. This observation was recently confirmed in the Western Canada melanoma study. ${ }^{1}$ The relation between exposure to sun and the subsequent development of melanoma, however, is by no means clear as the picture of a "typical" patient with malignant melanoma emerging from epidemiological studies in the United Kingdom is a youngish woman (women are twice as often affected as men) who is an indoor worker and of high socioeconomic status. ${ }^{2}$ This is clearly not the group of individuals who over a lifetime have the highest total dose of exposure to sunlight. Many dermatologists still recommend therapeutic doses of artificial sunlight (UVB) as an aid to the management of patients with psoriasis who are also receiving either topical tar or topical dithranol treatment. In the past decade UVA or long wave ultraviolet light in the form of a treatment known as PUVA (photochemotherapy) for patients with severe forms of psoriasis has also been widely used. Two large studies of patients with psoriasis have recently suggested that despite the use of UVB over many years there is no evidence of an increased incidence of skin cancer or indeed of any other form of malignancy by comparison with age matched controls. ${ }^{3}{ }^{4}$ Thus it would appear that the patient with psoriasis who receives long term UVB treatment as part of his antipsoriatic treatment is at no increased risk of developing any form of cutaneous malignancy, either basal cell carcinoma, squamous carcinoma, or malignant melanoma. Another time honoured treatment for psoriasis, topical tar, is also a recognised cutaneous carcinogen, but once again there is no statistically significant increase in cutaneous malignancy in those patients who have received tar treatment for several decades. This apparent protection of the patient with psoriasis from any increase in cutaneous malignancy despite the use of these forms of treatment is not understood. The conclusion so far as PUVA and subsequent cutaneous malignancy are concerned is not yet well established. A longer period will have to elapse before a definite statement on its safety may be made.-RONA MACKIE, professor of dermatology, Glasgow.

' Elwood JM, Gallagher RP, Hill GB, Spinelli JJ, Pearson JCG, Threlfall W. Pigmentation and skin reaction to sun as risk factors for cutan aneous melanom 2 Lee JAH. Melanoma and exposure to sunlight. Epidemiol Rev 1982;4:110-36.

3 Jacobs PH, Faber EM, Nall ML. Pscriasis and skin cancer. In: Farber EM, Cox AJ, eds. New York: Yorke Medical Books, 1977:350-2 Aderson MR, Clarke JA. Cancer incidence in patients with psoriasis. Br $\mathcal{F}$ Cancer
$1983 ; \mathbf{4 7}: 857-9$.

Cod liver oil is a rich source of unsaturated fatty acid. The role of unsaturated fatty acids in the prevention of atherosclerotic arterial disease has been widely discussed. Is there any evidence that, for this reason, cod liver oil supplements may lessen the tendency to develop atherosclerotic arterial disease in later life?

I know of no evidence that cod liver oil supplements lessen the tendency to develop atherosclerosis. The amount of unsaturated fatty acid in cod liver oil compared with that in the diet as a whole would, I imagine, be relatively small. Studies have shown that babies fed on milks containing fats with a high percentage of unsaturated fatty acids have relatively high fractions of unsaturated fatty acid in their adipose tissue store but they revert quickly to the usual pattern when they are placed on a normal diet. Furthermore, with the administration of cod liver oil comes a risk of giving excessive amounts of vitamin D.D HULL, professor of child health, Nottingham. 